Alain Combes
Marco Ranieri

\section{Rescue therapy for refractory ARDS should be offered early: yes}

Received: 13 February 2015

Accepted: 25 February 2015

Published online: 20 March 2015

(C) Springer-Verlag Berlin Heidelberg and ESICM 2015

For contrasting viewpoints, please go to

doi:10.1007/s00134-015-3704-6 and doi:10.1007/s00134-015-3708-2.

\section{A. Combes ( $)$}

Service de Réanimation Médicale, Groupe Hospitalier PitiéSalpêtrière, iCAN, Institute of Cardiometabolism and Nutrition, 47 Boulevard de L'Hôpital, 75651 Paris Cedex 13, France e-mail: alain.combes@psl.aphp.fr

\section{Ranieri}

Università "La Sapienza" di Roma, Policlinico Umberto I, Anesthesia and Critical Care Medicine, Rome, Italy e-mail: mranieri@unito.it

Clinical vignette A previously healthy 51-year-old woman (height $165 \mathrm{~cm}$, weight $60 \mathrm{~kg}$ ) was admitted to the ICU with severe community acquired pneumonia. She required intubation and mechanical ventilation $6 \mathrm{~h}$ after admission. Her respiratory status declined continuously over the next few hours. Twelve hours after admission, blood gases were as follows: $\mathrm{pH}=7.36, \mathrm{PaCO}_{2}=$ $47 \mathrm{mmHg}, \mathrm{PaO}_{2}=65 \mathrm{mmHg}, \mathrm{HCO}_{3}{ }^{-}=26 \mathrm{mmol} / \mathrm{L}$ on $\mathrm{FiO}_{2}=100 \%$, Vt set at $340 \mathrm{ml}$, PEEP at $8 \mathrm{cmH}_{2} \mathrm{O}$, respiratory rate at $28 / \mathrm{min}$, and plateau pressure measured at $28 \mathrm{cmH}_{2} \mathrm{O}$. She was hemodynamically stable and had a normal renal function.

This patient has severe ARDS according to the Berlin definition [1]. This patient has very low respiratory system compliance $\left(18 \mathrm{ml} / \mathrm{cmH}_{2} \mathrm{O}\right)$ and is ventilated with a high driving pressure $\left(20 \mathrm{cmH}_{2} \mathrm{O}\right)$. Hypoxemia is extremely severe with a high oxygenation index $\left(43 \mathrm{cmH}_{2} \mathrm{O} / \mathrm{mmHg}\right)$. Recent clinical studies showed that hospital mortality in patients experiencing such severe forms of ARDS ranges from 45 to $60 \%$ [1-6].

\section{What are the first-line options in this situation?}

This patient receives only $8 \mathrm{cmH}_{2} \mathrm{O}$ of PEEP. While higher PEEP confers a survival advantage in severe ARDS patients [7], higher levels of PEEP in this patient very likely will further increase the plateau pressure to levels that are certainly associated with an increased risk of ventilator-induced lung injury. Inhaled nitric oxide might have improved arterial oxygenation although this intervention was not shown to improve long-term survival. On the other hand, prone positioning should be rapidly initiated for more than $16 \mathrm{~h}$ since a significant increase in survival [8] has been observed in patients with severe ARDS with this maneuver. This patient should also receive continuous infusion of neuromuscular blockade agents [9].

\section{What is the rationale for applying "ultraprotective" MV in this situation?}

Lung hyperinflation occurs in approximately $30 \%$ of ARDS patients ventilated using the protective ARDSNet strategy [10]. Moreover, Hager and co-workers retrospectively analyzing data of the "ARDSNet" trial group show a linear relationship between mortality and $P_{\text {plat }}-$ a linear relationship in the sense that the lower $P_{\text {plat }}$, the lower the mortality, even for $P_{\text {plat }}$ less than $30 \mathrm{cmH}_{2} \mathrm{O}$ [11]. In a proof of concept study, Terragni et al. [12] demonstrated that very low tidal volume ventilation 
$\left(3.5-5 \mathrm{ml} / \mathrm{kg}\right.$ ) and lower $P_{\text {plat }}$ (less than $25 \mathrm{cmH}_{2} \mathrm{O}$ ) enhance lung protection as indicated by the significant attenuation of the pro-inflammatory signal observed a the pulmonary level.

Because Vt reduction to below $6 \mathrm{ml} / \mathrm{kg}$ to achieve $P_{\text {plat }}$ less than $25 \mathrm{cmH}_{2} \mathrm{O}$ may induce severe hypercapnia, this "ultraprotective" MV strategy may not be possible without the recourse to extracorporeal carbon dioxide removal $\left(\mathrm{ECCO}_{2}-\mathrm{R}\right)$ which only provides $\mathrm{CO}_{2}$ removal or venovenous extracorporeal membrane oxygenation (ECMO) which achieves complete extracorporeal blood oxygenation and $\mathrm{CO}_{2}$ removal.

\section{Why should ECMO be initiated rapidly in this patient?}

The patient's lung mechanics and blood gases should be carefully monitored during the prone positioning trial and after turning the patient back to the supine position. In the situation of major improvement of lung compliance and blood oxygenation following this trial, conventional MV should be continued until the patient can be safely extubated. Alternatively, if low respiratory system compliance and severe hypoxemia persist, venovenous ECMO should be instituted as soon as possible for the following reasons.

First, to achieve "ultraprotective" low volume and low pressure MV in this severely hypoxemic patient, ECMO should be preferred over $\mathrm{ECCO}_{2}-\mathrm{R}$. Under ECMO, Vt should be dramatically reduced to achieve $P_{\text {plat }}$ less than $25 \mathrm{cmH}_{2} \mathrm{O}$, with PEEP greater than $12 \mathrm{cmH}_{2} \mathrm{O}$, since these settings were shown to be independently associated with better outcomes [4, 13].

Second, modern ECMO devices are simpler, safer, require less anticoagulation, and are associated with fewer bleeding complications and it is now possible to support patients for weeks [14].

Third, recent series and a randomized trial demonstrated better survival for patients receiving ECMO for severe ARDS $[2-4,15]$. The CESAR trial [3] evaluated a strategy of transfer to a single center which had ECMO capability while the patients randomized to the control group received conventional MV. Mortality or severe disability 6 months after randomization was lower for the 90 patients randomized to the ECMO group ( 37 vs $53 \%$, $p=0.03)$. Interestingly, more than $60 \%$ of the randomized patients suffered pneumonia and their mean $\mathrm{PaO}_{2} / \mathrm{FiO}_{2}(76 \mathrm{mmHg}$ ) was higher than that of the patient described herein. A British collaborative cohort series of pandemic influenza A (H1N1)-induced ARDS patients also showed significantly lower mortality ( 24 vs $51 \%$ ) after propensity matching for 80 patients transferred to ECMO referral centers [2].

Fourth, factors strongly associated with poorer outcomes in series of severe ARDS patients receiving ECMO were older age, a greater number of days of MV before ECMO, a higher number of organ failures, low preECMO respiratory system compliance, absence of paralysis or prone positioning before ECMO, and immunosuppression $[15,16]$. Based on these factors, predictive survival models have been developed to help clinicians select appropriate candidates for ECMO. Interestingly, according to the recently developed RESP [15] and PRESERVE [16] scoring systems, hospital mortality after ECMO initiation would be less than $20 \%$ for the patient described above, should ECMO support be initiated within $48 \mathrm{~h}$ of tracheal intubation.

Lastly, a high incidence of cognitive impairment and psychiatric symptoms was demonstrated in long-term survivors of acute lung injury in the Fluid and Catheter Treatment Trial [17]. In that study, lower $\mathrm{PaO}_{2}$ [86 (70-98) vs 71 (67-80) $\mathrm{mmHg}, p=0.02]$ was associated with cognitive and psychiatric impairment 12 months following randomization. It can therefore be hypothesized that ECMO might improve long-term quality-of-life and cognitive function by improving blood oxygenation in severely hypoxemic ARDS patients. Indeed, patients randomized to the ECMO arm of the CESAR trial [3] or the 67 long-term survivors of the French multicenter ECMO-treated ARDS cohort [16] exhibited comparable or better of health-related quality-of-life scores than those reported by patients with less severe ARDS treated with conventional management [18].

In conclusion, a strong pathophysiological rationale and data from recent studies of ECMO for severe ARDS argue for the early initiation of ECMO in the patient described above. This strategy might decrease mortality from $45-50 \%$ to less than $20 \%$, with potentially less cognitive and psychiatric impairment and improved health-related quality-of-life in long-term survivors. The currently ongoing ECMO to Rescue Lung Injury in Severe ARDS (EOLIA) trial (NCT01470703) [19], an international multicenter randomized controlled trial comparing conventional MV with prone positioning to ECMO in very severe ARDS patients $\left(\mathrm{PaO}_{2} / \mathrm{FiO}_{2}\right.$ less than $80 \mathrm{mmHg}$ ), might confirm this hypothesis. 
Conflicts of interest Dr. Combes is the primary investigator of the EOLIA trial, NCT01470703, a randomized trial of VV-ECMO supported in part by MAQUET. Dr. Combes has received honoraria for lectures from MAQUET. Prof. Ranieri consulted for Hemodec, ALung, Maquet. He also lectured for Novalung. He was the PI of a Maquet supported trial on ECCO2R in patients with COPD.

\section{References}

1. Ranieri VM, Rubenfeld GD, Thompson BT, Ferguson ND, Caldwell E, Fan E, Camporota L, Slutsky AS (2012) Acute respiratory distress syndrome: the Berlin definition. JAMA 307:2526-2533

2. Noah MA, Peek GJ, Finney SJ, Griffiths MJ, Harrison DA, Grieve R, Sadique MZ, Sekhon JS, McAuley DF, Firmin RK, Harvey C, Cordingley JJ, Price S, Vuylsteke A, Jenkins DP, Noble DW, Bloomfield R, Walsh TS, Perkins GD, Menon D, Taylor BL, Rowan KM (2011) Referral to an extracorporeal membrane oxygenation center and mortality among patients with severe 2009 influenza $\mathrm{A}(\mathrm{H} 1 \mathrm{~N} 1)$. JAMA 306:1659-1668

3. Peek GJ, Mugford M, Tiruvoipati R, Wilson A, Allen E, Thalanany MM, Hibbert CL, Truesdale A, Clemens F, Cooper N, Firmin RK, Elbourne D (2009) Efficacy and economic assessment of conventional ventilatory support versus extracorporeal membrane oxygenation for severe adult respiratory failure (CESAR): a multicentre randomised controlled trial. Lancet 374:1351-1363

4. Pham T, Combes A, Roze H, Chevret S, Mercat A, Roch A, Mourvillier B, AraSomohano C, Bastien O, Zogheib E, Clavel M, Constan A, Marie Richard JC, Brun-Buisson C, Brochard L (2013) Extracorporeal membrane oxygenation for pandemic influenza $A(\mathrm{H} 1 \mathrm{~N} 1)$ induced acute respiratory distress syndrome: a cohort study and propensity-matched analysis. Am J Respir Crit Care Med 187:276-285

5. Young D, Lamb SE, Shah S, MacKenzie I, Tunnicliffe W, Lall R, Rowan K, Cuthbertson BH (2013) High-frequency oscillation for acute respiratory distress syndrome. $\mathrm{N}$ Engl $\mathrm{J}$ Med 368:806-813

6. Meade MO, Cook DJ, Guyatt GH, Slutsky AS, Arabi YM, Cooper DJ, Davies AR, Hand LE, Zhou Q, Thabane L, Austin P, Lapinsky S, Baxter A, Russell J, Skrobik Y, Ronco JJ, Stewart TE (2008) Ventilation strategy using low tidal volumes, recruitment maneuvers, and high positive endexpiratory pressure for acute lung injury and acute respiratory distress syndrome: a randomized controlled trial. JAMA 299:637-645
7. Briel M, Meade M, Mercat A, Brower RG, Talmor D, Walter SD, Slutsky AS, Pullenayegum E, Zhou Q, Cook D, Brochard L, Richard JC, Lamontagne F, Bhatnagar N, Stewart TE, Guyatt G (2010) Higher vs lower positive endexpiratory pressure in patients with acute lung injury and acute respiratory distress syndrome: systematic review and meta-analysis. JAMA 303:865-873

8. Guerin C, Reignier J, Richard JC, Beuret P, Gacouin A, Boulain T, Mercier E, Badet M, Mercat A, Baudin O, Clavel M, Chatellier D, Jaber S, Rosselli S, Mancebo J, Sirodot M, Hilbert G, Bengler C, Richecoeur J, Gainnier M, Bayle F, Bourdin G, Leray V, Girard R, Baboi L, Ayzac L (2013) Prone positioning in severe acute respiratory distress syndrome. $\mathrm{N}$ Engl $\mathrm{J}$ Med 368:2159-2168

9. Papazian L, Forel JM, Gacouin A, PenotRagon C, Perrin G, Loundou A, Jaber S, Arnal JM, Perez D, Seghboyan JM, Constantin JM, Courant P, Lefrant JY, Guerin C, Prat G, Morange S, Roch A (2010) Neuromuscular blockers in early acute respiratory distress syndrome. N Engl J Med 363:1107-1116

10. Terragni PP, Rosboch G, Tealdi A, Corno E, Menaldo E, Davini O, Gandini G, Herrmann P, Mascia L, Quintel M, Slutsky AS, Gattinoni L, Ranieri VM (2007) Tidal hyperinflation during low tidal volume ventilation in acute respiratory distress syndrome. Am J Respir Crit Care Med 175:160-166

11. Hager DN, Krishnan JA, Hayden DL, Brower RG (2005) Tidal volume reduction in patients with acute lung injury when plateau pressures are not high. Am J Respir Crit Care Med 172:1241-1245

12. Terragni PP, Del Sorbo L, Mascia L, Urbino R, Martin EL, Birocco A, Faggiano C, Quintel M, Gattinoni L, Ranieri VM (2009) Tidal volume lower than $6 \mathrm{ml} / \mathrm{kg}$ enhances lung protection: role of extracorporeal carbon dioxide removal. Anesthesiology 111:826-835

13. Schmidt M, Stewart C, Bailey M, Nieszkowska A, Kelly J, Murphy L, Pilcher D, Cooper DJ, Scheinkestel C, Pellegrino V, Forrest P, Combes A, Hodgson C (2015) Mechanical ventilation management during extracorporeal membrane oxygenation for acute respiratory distress syndrome: a retrospective international multicenter study. Crit Care Med 43:654-664
14. MacLaren G, Combes A, Bartlett RH (2012) Contemporary extracorporeal membrane oxygenation for adult respiratory failure: life support in the new era. Intensive Care Med 38:210-220

15. Schmidt M, Bailey M, Sheldrake J, Hodgson C, Aubron C, Rycus PT, Scheinkestel C, Cooper DJ, Brodie D, Pellegrino V, Combes A, Pilcher D (2014) Predicting survival after extracorporeal membrane oxygenation for severe acute respiratory failure. The respiratory extracorporeal membrane oxygenation survival prediction (RESP) score. Am J Respir Crit Care Med 189:1374-1382

16. Schmidt M, Zogheib E, Roze H, Repesse X, Lebreton G, Luyt CE, Trouillet JL, Brechot N, Nieszkowska A, Dupont H, Ouattara A, Leprince P, Chastre J, Combes A (2013) The PRESERVE mortality risk score and analysis of longterm outcomes after extracorporeal membrane oxygenation for severe acute respiratory distress syndrome. Intensiv Care Med 39:1704-1713

17. Mikkelsen ME, Christie JD, Lanken PN, Biester RC, Thompson BT, Bellamy SL, Localio AR, Demissie E, Hopkins RO, Angus DC (2012) The adult respiratory distress syndrome cognitive outcomes study: long-term neuropsychological function in survivors of acute lung injury. Am J Respir Crit Care Med 185:1307-1315

18. Herridge MS, Cheung AM, Tansey CM, Matte-Martyn A, Diaz-Granados N, AlSaidi F, Cooper AB, Guest CB, Mazer CD, Mehta S, Stewart TE, Barr A, Cook D, Slutsky AS (2003) One-year outcomes in survivors of the acute respiratory distress syndrome. N Engl J Med 348:683-693

19. ClinicalTrial.gov (2014) EOLIA trial. http://www.clinicaltrials.gov/ct2/show/ NCT01470703?term=eolia\&rank=1. Accessed 14 Sept 2014 